\title{
LETTER
}

\section{Role of carotid ultrasonography in the evaluation of cardiovascular risk in patients with rheumatoid arthritis}

\author{
Miguel A Gonzalez-Gay ${ }^{\dagger 1}$, Carlos Gonzalez-Juanatey², Jose A Miranda-Filloy³, Javier Martin ${ }^{4}$ and Javier Llorca ${ }^{*+5,6}$ \\ See related research by Södergren et al., http://arthritis-research.com/content/12/4/R158
}

We read with great interest the article by Södergren and colleagues in a recent issue of Arthritis Research \& Therapy ('Atherosclerosis in early rheumatoid arthritis: very early endothelial activation and rapid progression of intima media thickness') [1]. In the study reported in the article, the authors showed no differences of carotid artery intima-media thickness (IMT) in patients with very early rheumatoid arthritis (RA) compared with controls at baseline [1]. However, in the subgroup of individuals who were re-evaluated 18 months after the first ultrasound measurement, the carotid IMT had increased significantly among the patients with RA. However, this was not the case for the controls [1].

With respect to these interesting observations, we would like to further emphasize the importance of carotid ultrasonography in the evaluation of the cardiovascular risk of patients with RA and the importance of the duration of the disease as a predictor of severity, so it can influence the development of cardiovascular events in these patients. We previously reported that, in longstanding RA patients with no classic cardiovascular risk factors at the time of the carotid assessment, the duration of the disease was the best predictor of carotid plaques [2]. On the other hand, RA is a chronic inflammatory disease, and even in the apparently quiescent phases of the disease, the cumulative effect of the chronic inflammatory burden may account for the progression of the atherosclerosis disease. In this regard, we observed that the mean values of C-reactive protein (CRP) over an extended follow-up rather than a single determination of CRP at the time of the carotid ultrasonography

\footnotetext{
${ }^{\dagger} \mathrm{MAG}-\mathrm{G}$ and $\mathrm{JL}$ share senior authorship.

*Correspondence: Ilorcaj@unican.es

${ }^{5}$ Division of Epidemiology and Computational Biology, School of Medicine, University of Cantabria, Avda. Herrera Oria s/n, 39011 -Santander, Spain. Full list of author information is available at the end of the article
}

evaluation were associated with the carotid IMT [3]. Moreover, we found that carotid artery IMT had a high predictive power for the development of cardiovascular events over a 5-year follow-up period in 47 patients with RA without clinically evident cardiovascular disease at the time of the carotid ultrasonography evaluation [4]. In our study, carotid IMT categorized in quartiles was strongly associated with the development of cardiovascular events [4]. When logistic regression models were performed, carotid IMT at the time of the ultrasonographic study yielded a high predictive power for the development of cardiovascular events over the 5 -year follow-up period. On the other hand, the duration of the disease is also considered an important risk factor of future cardiovascular events [5].

Taking all of these considerations together, we propose that ultrasonographic assessment of the carotid artery be performed on all patients with RA in order to establish a subgroup of patients with a high risk of cardiovascular complications. This procedure should be carried out at the time of the disease diagnosis and periodically thereafter, in particular in those patients with severe disease and persistent elevation of markers of inflammation.

\section{Abbreviations}

CRP, C-reactive protein; IMT, intima-media thickness; RA, rheumatoid arthritis.

\section{Competing interests}

The authors declare that they have no competing interests.

\section{Author details}

'Division of Rheumatology, Hospital Universitario Marqués de Valdecilla, IFIMAV, Avda. Valdecilla, 39008-Santander, Spain. ²Division of Cardiology, Hospital Xeral-Calde, Rua Dr. Ochoa s/n, 27004-Lugo, Spain. ${ }^{3}$ Division of Rheumatology, Hospital Xeral-Calde, Rua Dr. Ochoa s/n, 27004-Lugo, Spain. ${ }^{4}$ Consejo Superior de Investigaciones Cientificas, Avda. del conocimiento s/n, 18100 Armilla (Granada), Spain. ${ }^{5}$ Division of Epidemiology and Computational Biology, School of Medicine, University of Cantabria, Avda. Herrera Oria s/n, 39011-Santander, Spain. ' CIBER Epidemiología y Salud Pública (CIBERESP), IFIMAV, Spain.

Published: 16 December 2010 


\section{References}

1. Södergren A, Karp K, Boman K, Eriksson C, Lundström E, Smedby T, Söderlund L, Rantapää-Dahlqvist S, Wållberg-Jonsson S: Atherosclerosis in early rheumatoid arthritis: very early endothelial activation and rapid progression of intima media thickness. Arthritis Res Ther 2010, 12:R158

2. Gonzalez-Juanatey C, Llorca J, Testa A, Revuelta J, Garcia-Porrua C, GonzalezGay MA: Increased prevalence of severe subclinical atherosclerotic findings in long-term treated rheumatoid arthritis patients without clinically evident atherosclerotic disease. Medicine (Baltimore) 2003, 82:407-413.

3. Gonzalez-Gay MA, Gonzalez-Juanatey C, Piñeiro A, Garcia-Porrua C, Testa A, Llorca J: High-grade C-reactive protein elevation correlates with accelerated atherogenesis in patients with rheumatoid arthritis. J Rheumatol 2005, 32:1219-1223.

4. Gonzalez-Juanatey C, Llorca J, Martin J, Gonzalez-Gay MA: Carotid intima-media thickness predicts the development of cardiovascular events in patients with rheumatoid arthritis. Semin Arthritis Rheum 2009, 38:366-371

5. Peters MJ, Symmons DP, McCarey D, Dijkmans BA, Nicola P, Kvien TK, Mclnnes IB, Haentzschel H, Gonzalez-Gay MA, Provan S, Semb A, Sidiropoulos P, Kitas G, Smulders YM, Soubrier M, Szekanecz Z, Sattar N, Nurmohamed MT: EULAR evidence-based recommendations for cardiovascular risk management in patients with rheumatoid arthritis and other forms of inflammatory arthritis. Ann Rheum Dis 2010, 69:325-331.

doi:10.1186/ar3186

Cite this article as: Gonzalez-Gay MA, et al.: Role of carotid ultrasonography in the evaluation of cardiovascular risk in patients with rheumatoid arthritis. Arthritis Research \& Therapy 2010, 12:409. 